\title{
GAYA KEPEMIMPINAN DAN DISIPLIN KERJA TERHADAP KINERJA ANGGOTA POLRI DAN ASN DI DITRESKRIMUM POLDA SUMSEL
}

\author{
Elliya Effendi \\ Ditreskrimum Polda Sumatera Selatan \\ Email : Ellya@gmail.com \\ Luis Marnisah \\ Program Magister Universitas Indo Global Mandiri Palembang \\ Email : luismarnisah@uigm.ac.id \\ DOI : 10.35908/jeg.v4i2.753 \\ Received: May 30, 2019, Revised: June 30, 2019, Accepted: July 30, 2019
}

\begin{abstract}
This study aims to determine: (1) Effect of leadership style on the performance of National Police and ASN Members Ditreskrimum of North Sumatra Regional Police. (2) The Effect of Work Discipline on the Performance of Members of the Police and ASN Ditreskrimum of the South Sumatra Regional Police. (3) Effect of leadership style and work discipline on the performance of National Police and ASN Members Ditreskrimum of North Sumatra Regional Police.

This study is categorized as a quantitative associative causal study with an instrument in the form of a questionnaire. The population in this study were 132 members of the National Police and South Sumatra Regional Police ASN. Sampling technique using Sampling Proposal. The sample in this study was to take a population or as many as 132 samples. Data collection using questionnaires and interviews. Test the validity of the instrument using Confirmatory Factor Analysis, while the reliability test uses Cronbach Alpha. The measuring instrument proved to be valid and reliable for research instruments. Multiple regression analysis is used to test the hypothesis of this study.

The results of the study found that: (1) Leadership Style had a positive and significant effect on the performance of Polri and ASN Members Ditreskrimum of North Sumatra Regional Police using the $t$ test that $t$ counted 6.499> with $t$ table 1.993 with a significance of $0.00<0.05$, Contributing leadership style to the performance of National Police and ASN Members Ditreskrimum of North Sumatra Regional Police is 50\%. (2) Work discipline has a significant positive effect on the performance of National Police and ASN Members Ditreskrimum South Sumatra Police using t test that $t$ count 4.021> with t table 1.993 with a significance of $0.025<0.05$, Contribution of work discipline to the performance of National Police and ASN Members Ditreskrimum Polda Sumsel by 25\%. (3) Leadership style and work discipline have a positive and significant effect on the performance of National Police and ASN Members Ditreskrimum South Sumatra Police using the F test that F count 9.980> with F table 1993 with significance $0.04<0.05$, Contributions of leadership style and work discipline to explain performance Members of the Indonesian National Police and ASN Ditreskrimum Sumsel Polda amounted to $40 \%$.
\end{abstract}

Keywords: Leadership Style, Work Discipline, Employee Performance

\begin{abstract}
ABSTRAK
Penelitian ini bertujuan untuk mengetahui : (1) Pengaruh gaya kepemimpinan terhadap Kinerja Anggota Polri dan ASN Ditreskrimum Polda Sumsel . (2) Pengaruh Disiplin Kerja terhadap Kinerja Anggota Polri dan ASN Ditreskrimum Polda Sumsel . (3) Pengaruh gaya kepemimpinan dan disiplin kerja terhadap Kinerja Anggota Polri dan ASN Ditreskrimum Polda Sumsel .

Penelitian ini dikategorikan sebagai penelitian kausal asosiatif pendekatan kuantitatif dengan instrumen berupa kuesioner. Populasi dalam penelitian ini adalah sebagian dari anggota Polri dan
\end{abstract}


ASN Polda Sumsel sebanyak 132 orang. Teknik pengambilan sampel dengan cara Proposif Sampling. Sampel dalam penelitian ini adalah dengan mengambil populasi atau sebanyak 132 sampel. Pengumpulan data menggunakan kuesioner dan wawancara. Uji validitas instrumen menggunakan Confirmatory Factor Analysis, sedangkan uji reliabilitas menggunakan Cronbach Alpha. Alat ukur terbukti valid dan reliabel untuk instrumen penelitian. Analisis regresi berganda digunakan untuk uji hipotesis penelitian ini.

Hasil penelitian menemukan bahwa : (1) Gaya Kepemimpinan berpengaruh positif dan signifikan terhadap kinerja Anggota Polri dan ASN Ditreskrimum Polda Sumsel menggunakan uji t bahwa t hitung 6,499 > dengan t tabel 1.993 dengan signifikansi sebesar $0,00<0,05$, Kontribusi gaya kepemimpinan terhadap kinerja Anggota Polri dan ASN Ditreskrimum Polda Sumsel sebesar $50 \%$. (2) Disiplin kerja berpengaruh positip signifikan terhadap kinerja Anggota Polri dan ASN Ditreskrimum Polda Sumsel menggunakan uji t bahwa t hitung 4.021 > dengan t tabel 1.993 dengan signifikansi sebesar 0,025 $<0,05$,Kontribusi disiplin kerja terhadap kinerja Anggota Polri dan ASN Ditreskrimum Polda Sumsel sebesar 25\%. (3) Gaya Kepemimpinan dan disiplin kerja berpengaruh positif dan signifikan terhadap kinerja Anggota Polri dan ASN Ditreskrimum Polda Sumsel menggunakan uji $\mathrm{F}$ bahwa $\mathrm{F}$ hitung 9,980 > dengan $\mathrm{F}$ tabel 1.993 dengan signifikansi $0.04<0,05$, Kontribusi gaya kepemimpinan dan disiplin kerja untuk menjelaskan kinerja Anggota Polri dan ASN Ditreskrimum Polda Sumsel sebesar $40 \%$.

Kata Kunci : Gaya Kepemimpinan, Disiplin Kerja, Kinerja Pegawai.

\section{Pendahuluan}

\subsection{Latar Belakang}

Kehadiran seorang anggota Polri akan berpengaruh terhadap kualitas kerja, sehingga instansi perusahaan tidak bisa mencapai tujuan secara optimal. Absensi anggota Polri pada Direktorat Reserse Kriminal Umum Polda Sumsel di tahun 2018 seperti tertera pada tabel 1.1 berikut :

Tabel 1.1

Tingkat Kehadiran Kerja Personil Ditreskrimum Polda Sumsel Tahun 2017- 2018

\begin{tabular}{|c|c|c|c|c|c|c|c|}
\hline \multirow{2}{*}{ No. } & \multirow{2}{*}{ Bulan } & \multirow{2}{*}{$\begin{array}{c}\text { Jml } \\
\text { Personil }\end{array}$} & \multicolumn{2}{|c|}{2017} & \multirow{2}{*}{$\begin{array}{l}\text { Jml } \\
\text { Personil }\end{array}$} & \multicolumn{2}{|c|}{2018} \\
\hline & & & Hadir & $\%$ & & Hadir & $\%$ \\
\hline 1 & 2 & 3 & 4 & 5 & 6 & 7 & 8 \\
\hline 01 & Januari & 230 & 79 & 34,34 & 238 & 82 & 34,45 \\
\hline 02 & Februari & 230 & 87 & 37,82 & 238 & 79 & 33,19 \\
\hline 03 & Maret & 230 & 94 & 40,86 & 238 & 96 & 40,33 \\
\hline 04 & April & 230 & 60 & 26,08 & 238 & 120 & 50,42 \\
\hline 05 & Mei & 232 & 76 & 32,75 & 240 & 123 & 51,25 \\
\hline 06 & Juni & 232 & 89 & 38,36 & 240 & 126 & 52,5 \\
\hline 07 & Juli & 234 & 90 & 38,46 & 240 & 120 & 50 \\
\hline 08 & Agustus & 234 & 101 & 43,16 & 240 & 121 & 50,41 \\
\hline 09 & September & 234 & 103 & 44,01 & 242 & 132 & 54,54 \\
\hline 10 & Oktober & 234 & 105 & 44,87 & 242 & 141 & 58,26 \\
\hline 11 & November & 234 & 110 & 47,00 & 242 & 129 & 53,30 \\
\hline 12 & Desember & 234 & 104 & 44,44 & 243 & 130 & 53,49 \\
\hline
\end{tabular}

Sumber : Ditreskrimum Polda Sumsel, 2018. 
Berdasarkan Tabel 1.1, untuk absensi yang terukur dalam tahun 2018, dapat dilihat bahwa anggota Polri yang disiplin kerja masih sangat rendah pada Bulan ke I sebanyak 34,34 \%, pada Bulan 2 menjadi 37,82 \% pada Bulan 3naik sebesar 40,86\% dan pada Bulan 5 sebesar $32,75 \%$ pada Bulan April paling rendah kehadiran anggota Polri mencapai 26,08 \% dikarenakan pada bulan tersebut ada anggota Polri dan ASN Polri yang tidak absen karena terlambat, sakit, izin tidak masuk kerja, cuti tahunan, karena masih tingginya ketidaksadaran dan kesediaan mentaati peraturan Instansi perusahaan dan mencerminkan kurangnya rasa tanggung jawab terhadap tugas-tugas yang diberikan dapat dilihat dari disiplin kerja anggota Polri, menyebabkan menurunnya kinerja anggota Polri di Direktorat Reserse Kriminal Umum Polda Sumsel.

Gaya kepemimpinan yang meliputi keramahan sikap, sikap saling menghargai di waktu yang berbeda pendapat, dan lain sebagainya adalah syarat wajib untuk terus membina kualitas pemikiran anggota Polri yang akhirnya bisa membina kinerja mereka secara terus menerus.

Gaya kepemimpinan yang otoriter akan menyebabkan disiplin dan kinerja pegawai menurun. Fasilitas yang diberikan oleh pihak manajemen Direktorat Reserse Kriminal Umum Polda Sumsel sudah dapat dikatakan memadai, namun ada beberapa fasilitas yang kurang terawat dengan baik seperti pendingin ruangan, kendaraan roda empat yang rusak dan tempat parkir kurang memadai.

Berikut ini Tabel 1.2 daftar barang/fasilitas Direktorat Reserse Kriminal Umum Polda Sumsel Tahun 2017 - 2018 sebagai berikut :
Tabel 1.2

\section{Daftar Barang / Fasilitas Ditreskrimum} Polda SumselTahun 2017- 2018

\begin{tabular}{|c|l|c|c|}
\hline No. & $\begin{array}{c}\text { Nama Barang / } \\
\text { Fasilitas }\end{array}$ & Jumlah & Keterangan \\
\hline 1 & 2 & 3 & 4 \\
\hline 1. & AC & 20 & Baik \\
\hline 2. & Televisi & 6 & Baik \\
\hline 3. & Telepon & 2 & Baik \\
\hline 4. & Kulkas & 4 & Baik \\
\hline 5. & Komputer & 55 & Baik \\
\hline 6. & Printer & 55 & Baik \\
\hline
\end{tabular}

Sumber : Ditreskrimum Polda Sumsel, 2018

Berdasarkan data pra survey yang penulis laksanakan di Ditreskrimum Polda Sumsel mengenai faktor-faktor yang mempengaruhi menurunnya kinerja dari para pegawai yang bekerja disana, mendapatkan hasil sebagai berikut :

Tabel 1.3

\section{Faktor Yang harus mendapat perhatian lebih dari Satker untuk meningkatkan Kinerja Pegawai}

\begin{tabular}{|c|l|c|c|}
\hline No & \multicolumn{1}{|c|}{$\begin{array}{c}\text { Faktor Yang } \\
\text { Mempengaruhi }\end{array}$} & $\begin{array}{c}\text { Jumlah } \\
\text { Jawaban }\end{array}$ & $\%$ \\
\hline 1. & $\begin{array}{l}\text { Gaya } \\
\text { Kepemimpinan }\end{array}$ & 8 & $45 \%$ \\
\hline 2. & Disiplin Kerja & 12 & $55 \%$ \\
\hline \multicolumn{2}{|c|}{ Dari hasil pra survey tersbut, }
\end{tabular}
terlihat bahwa faktor tertinggi adalah Disiplin Kerja yaitu sebesar 55\% atau sebanyak 12 responden, dan faktor terendah adalah Gaya Kepemimpinan sebesar $45 \%$ atau sebanyak 8 responden. Berdasarkan latar belakang di atas, maka penelitian ini diberi judul "Gaya Kepemimpinan dan Disiplin Kerja terhadap Kinerja anggota Polri dan ASNdi Ditreskrimum Polda Sumsel”. 


\subsection{Rumusan Masalah}

Rumusan masalah dalam penelitian ini adalah :

a. Bagaimanakah pengaruh gaya kepemimpinan terhadap kinerja anggota Polri dan ASN di Ditreskrimum Polda Sumsel.

b. Bagaimanakah pengaruh disiplin kerja terhadap kinerja anggota Polri dan ASN di Ditreskrimum Polda Sumsel.

c. Bagaimanakah pengaruh gaya kepemimpinan dan disiplin kerja secara bersama terhadap kinerja anggota Polri dan ASN di Ditreskrimum Polda Sumsel.

\section{Kajian Pustaka}

\subsubsection{Gaya Kepemimpinan}

Dalam menyukseskan kepemimpinan dalam organisasi, pemimpin perlu memikirkan dan memperlihatkan gaya kepemimpinan yang akan diterapkan kepada pegawainya. Gaya kepemimpinan atasan dapat mempengaruhi kesuksesan pegawai dalam berprestasi, dan akan berujung pada keberhasilan organisasi dalam mencapai tujuannya (Suranta;2002;38).

\subsubsection{Disiplin Kerja}

Menurut Simamora (1997 : 746) disiplin adalah prosedur yang mengoreksi atau menghukum bawahan karena melanggar peraturan atau prosedur. Disiplin kerja adalah suatu alat yang digunakan para manajer untuk berkomunikasi dengan pegawai agar mereka bersedia untuk mengubah suatu perilaku serta sebagai suatu upaya untuk meningkatkan kesadaran dan kesediaan menaati semua peraturan perusahaan dan norma - norma sosial yang berlaku (Rivai : 2004 .33).

\subsubsection{Kinerja Pegawai}

Beberapa pengertian dari kinerja pegawai yaitu :

a. Hasibuan (2012 : 94) kinerja adalah suatu hasil kerja yang dicapai seseorang dalam melaksanakan tugas - tugas yang dibebankan kepadanya didasarkan atas kecakapan pengalaman dan kesungguhan serta waktu.

b. Yun (2007: 745) menjelaskan bahwa kinerja didefinisikan sebagai perilaku yang terlihat langsung dalam proses produksi barang atau jasa atau kegiatan yang memberikan dukungan langsung untuk proses teknis dari sebuah organisasi.

Faktor - faktor yang mempengaruhi kinerja pegawai menurut Sutrisno (2010 : 93-94) yaitu :

1) Efektifitas dan efisiensi

2) Otoritas dan Tanggung Jawab

3) Disiplin

4) Insiatif

\subsection{Kerangka Pemikiran}

Berdasarkan penjelasan di atas maka dibentuklah kerangka pemikirannya seperti diagram di bawah ini:

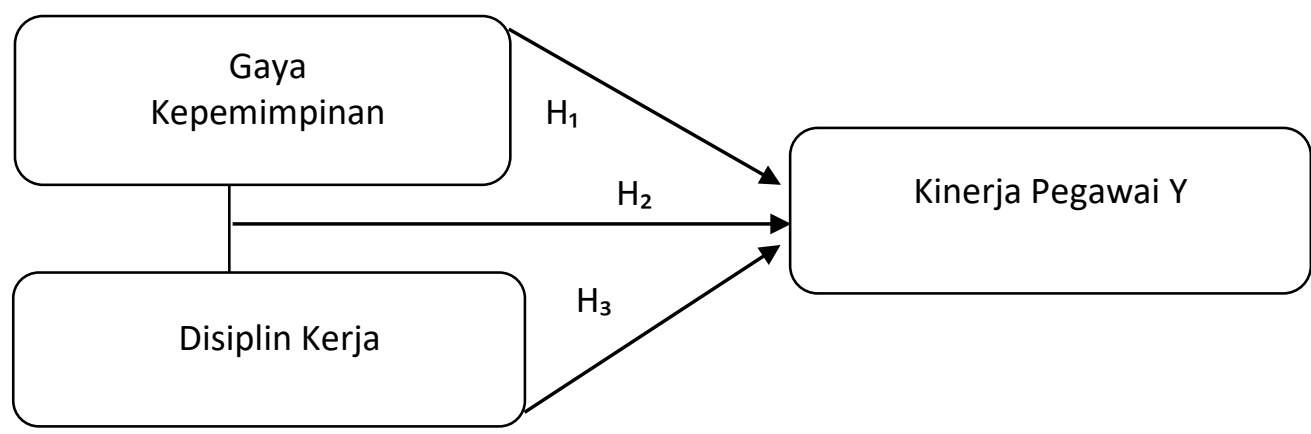

Gambar 2.1. Diagram Paradigma Penelitian 


\subsection{Pengujian Hipotesis}

Berikut ini hipotesis sesuai dengan variabel-variabel yang akan diteliti maka hipotesis yang akan diajukan dalam penelitian ini adalah :

$\mathrm{H}_{1}$ : diduga gaya kepemimpinan berpengaruh terhadap Kinerja anggota Polri dan ASN di Ditreskrimum Polda Sumsel.

$\mathrm{H}_{2}$ : diduga disiplin kerja berpengaruh siginifikan terhadap Kinerja anggota Polri dan ASN di Ditreskrimum Polda Sumsel.

$\mathrm{H}_{3}$ : diduga Gaya Kepemimpinan dan disiplin kerja berpengaruh positif secara bersama-sama.

\subsection{Penelitian Terdahulu}

Penelitian-penelitian

yang

menyangkut pengaruh gaya kepemimpinan dan disiplin kerja terhadap kinerja pegawai sebagai berikut :

1. Penelitian Hidayat, dkk (2006) dengan judul "Pengaruh Motivasi Kerja, Kemampuan Kerja dan Gaya Kepemimpinan terhadap Kinerja Karyawan pada Badan Kesatuan Bangsa dan Perlindungan Masyarakat Propinsi Jawa Tengah", dimana menghasilkan analisis bahwa motivasi kerja berpengaruh positif pada kinerja karyawan secara signifikan, kemampuan kerja berpengaruh positif pada kinerja karyawan secara signifikan, gaya kepemimpinan berpengaruh positif pada kinerja karyawan secara signifikan, dan secara simultan, ketiga variabel independen tersebut berpengaruh positif secara signifikan pada kinerja karyawan.
2. Harlie (2012) dengan judul penelitian "Pengaruh Disiplin Kerja, Motivasi dan Pengembangan Karier terhadap Kinerja PNS pada Pemkab Tabalong di Tanjung Kalimantan Selatan “, yang menemukan disiplin kerja, motivasi kerja dan pengembangan karier berpengaruh positif secara baik simultan maupun secara parsial pada Kinerja Pegawai Negeri Sipil.

3. Patiran (2010) dengan judul " Analisis Faktor - faktor yang Mempengaruhi Kinerja Pegawai Negeri Sipil “, hasil analisis menunjukkan bahwa disiplin kerja, pendidikan pegawai dan motivasi kerja memiliki pengaruh positif pada kinerja Pegawai Negeri Sipil baik secara simultan maupun secara parsial.

4. Suryafitra Muttaqin (2012) dalam jurnal Ekonomi dengan judul "Pengaruh Gaya Kepemimpinan terhadap Disiplin Kerja (Studi pada Karyawan PT. PLN (Persero) Area Pelayanan Malang)", The research goal are to examine influences of leadership style on work discipline. This research is explanatory research and use quantitative method. Seventy five sample has been taken from Employee of PT PLN (Persero) Malang Service Area.

5. Sabdo Teguh Prakoso (2011) dengan judul “ Pengaruh Gaya Kepemimpinan dan Disiplin Kerja terhadap Kinerja Pegawai Perum Perhutani KPH Kedu Utara", Penelitian ini merupakan penelitian survei dengan pendekatan kuantitatif. Sampel penelitian ini adalah pegawai Perum Perhutani KPH Kedu Utara berjumlah 150 pegawai dengan teknik pengambilan sampel populasi. Pengumpulan data menggunakan kuesioner sedangkan analisis data 
dilakukan dengan menggunakan analisis regresi berganda.

6. Cahyo Adi Nugroho (2013) dengan judul " Pengaruh Gaya Kepemimpinan dan Disiplin Kerja terhadap Kinerja Pegawai Dinas Pariwisata Daerah Istimewa Yogyakarta. "Penelitian ini dikategorikan sebagai penelitian kausal asosiatif pendekatan kuantitatif dengan instrumen berupa kuesioner. Populasi dalam penelitian ini adalah seluruh pegawai Dinas Pariwisata Daerah Istimewa Yogyakarta sebanyak 81 orang. Teknik pegambilan sampel dengan cara Proposif Sampling. Sampel dalam penelitian ini adalah dengan mengambil populasi atau sebanyak 81 sampel. Pengumpulan data menggunakan kuesioner dan wawancara.

7. Penelitian Suprayitno (2007) dengan judul pengaruh disiplin kerja, lingkungan kerja dan motivasi kerja terhadap kinerja karyawan. Hasil penelitian menunjukan variabel disiplin kerja berpengaruh signifikan terhadap kinerja karyawan Sub Dinas Kebersihan dan Tata Kota DPU LLAJ Kab Karanganyar. Hal ini ditunjukkan nilai signifikan sebesar 0,016 (probabilitas $0.016<0,05$ ). Variabel lingkungan kerja berpengaruh signifikan terhadap kinerja karyawan Sub Dinas Kebersihan dan Tata Kota DPU - LLAJ Kab Karang Anyar yang ditunjukkan oleh nilai Signifikan sebesar 0,014 (probabilitas $0,014<0.05$ ). Variabel motivasi kerja berpengaruh terhadap kinerja karyawan Sub Dinas Kebersihan dan Tata Kota DPU - LLAJ Kab Karang Anyar. Hal ini ditunjukkan dengan nilai sebesar 0.016 (probabilitas $0.006<0,05$ ).

\section{Metodologi Penelitian}

\subsection{Metode Penelitian}

Penelitian ini termasuk dalam kategori penelitian asosiatif kausal dengan menggunakan pendekatan kuantitatif. Penelitian asosiatif kausal adalah penelitian yang bertujuan untuk mengetahui pengaruh antara dua variabel atau lebih. Penelitian ini akan menjelaskan hubungan mempengaruhi dan dipengaruhi dari variabel - variabel yang akan diteliti, yaitu pengaruh variabel gaya kepemimpinan dan variabel disiplin kerja terhadap variabel kinerja pegawai.

Tabel 3.1

\section{Jumlah Sampel Personil Ditreskrimum Polda Sumsel}

\begin{tabular}{|c|l|c|c|}
\hline No & \multicolumn{1}{|c|}{2} & 3 & 4 \\
\hline 1 & \multicolumn{1}{|c|}{ Unit Bagian } & JumlahPegawai & Responden \\
\hline 1 & $\begin{array}{l}\text { Sub bag } \\
\text { Renmin }\end{array}$ & 34 & 25 \\
\hline 2 & Urkeu & 6 & 6 \\
\hline 3 & Bag Wassidik & 10 & 8 \\
\hline 4 & $\begin{array}{l}\text { Bag Bin } \\
\text { Opsnal }\end{array}$ & 16 & 8 \\
\hline 5 & Subdit I & 26 & 10 \\
\hline 6 & Subdit II & 33 & 20 \\
\hline 7 & Subdit III & 76 & 25 \\
\hline 8 & Subdit IV & 33 & 132 \\
\hline 9 & SieIdentifikasi & 12 & $\begin{array}{l}\text { Total } \\
\text { Keseluruhan }\end{array}$ \\
\hline
\end{tabular}

Sumber :Ditreskrimum Polda Sumsel, 2018

\subsection{Instrumen Penelitian}

Pemimpin anda sering menekankan pentingnya tugas dan meminta anda melaksanakan tugas dengan sebaik-baiknya", 8 pernyataan tentang 
disiplin kerja yang digunakan oleh Dharmawan (2011) dengan contoh pernyataan "Saya datang ke kantor tepat waktu", dan 5 pernyataan tentang kinerja pegawai yang digunakan oleh Ranupandojo (1984) dengan contoh pernyataan "Saya dapat diandalkan dan masuk kerja tepat waktu". Adapun kisi kisi dan instrumen penelitian adalah sebagai berikut :

Tabel 3.2.

\section{Kisi - kisi Instrumen Penelitian}

\begin{tabular}{|l|cc|c|}
\hline \multicolumn{1}{|c|}{ Variabel } & \multicolumn{2}{|c|}{ Indikator } & No Item \\
\hline $\begin{array}{l}\text { Kinerja } \\
\text { Pegawai }\end{array}$ & 2. & Motivasi & $14-15$ \\
& & Kepuasan Kerja & $16-17$ \\
\hline
\end{tabular}

\begin{tabular}{|l|ll|c|}
\hline 3. & Tingkat Stres & $18-19$ \\
4. & Kondisi Fisik & pekerjaan & $20-21$ \\
5. & Desain pekerjaan & $22-23-24$ \\
\hline
\end{tabular}

Sumber :Suprihatiningrum’ 2012

\section{Pembahasan Hasil Penelitian}

\section{1.Uji Validitas Variabel Penelitian}

Hasil Uji validitas untuk mengukur kaitan indikator dengan variabel penelitian, pada variabel gaya kepemimpinan adalah sebagai berikut;

Tabel 4.1.1

Validasi Variabel Gaya Kepemimpinan

\begin{tabular}{|l|c|c|c|c|}
\hline & $\begin{array}{c}\text { Scale Mean if } \\
\text { Item Deleted }\end{array}$ & $\begin{array}{c}\text { Scale Variance if } \\
\text { Item Deleted }\end{array}$ & $\begin{array}{c}\text { Corrected Item- } \\
\text { Total Correlation }\end{array}$ & $\begin{array}{c}\text { Cronbach's Alpha } \\
\text { if Item Deleted }\end{array}$ \\
\hline KEP.01 & 22.8939 & 2.767 & $\mathbf{0 . 3 9 0}$ & 0.481 \\
KEP.02 & 23.1591 & 2.898 & $\mathbf{0 . 3 3 0}$ & 0.460 \\
KEP.03 & 23.0985 & 3.067 & $\mathbf{0 . 3 6 9}$ & 0.320 \\
KEP.04 & 23.0455 & 2.853 & $\mathbf{0 4 2 6}$ & 0.319 \\
KEP.05 & 23.0455 & 3.051 & $\mathbf{0 . 5 6 2}$ & 0.327 \\
KEP.06 & 22.9318 & 3.163 & $\mathbf{0 . 5 2 8}$ & 0.446 \\
KEP.07 & 23.0985 & 2.761 & $\mathbf{0 . 6 1 7}$ & 0.415 \\
\hline
\end{tabular}

Sumber : Output SPSS Diolah'2018

Tabel 4.1.2

Validasi Variabel Disiplin Kerja

\begin{tabular}{|c|c|c|c|c|}
\hline & $\begin{array}{c}\text { Scale Mean if } \\
\text { Item Deleted }\end{array}$ & $\begin{array}{c}\text { Scale Variance if } \\
\text { Item Deleted }\end{array}$ & $\begin{array}{c}\text { Corrected Item- } \\
\text { Total Correlation }\end{array}$ & $\begin{array}{c}\text { Cronbach's Alpha } \\
\text { if Item Deleted }\end{array}$ \\
\hline DIS.01 & 27.1515 & 4.481 & $\mathbf{0 . 4 8 7}$ & 0.452 \\
DIS.02 & 27.1515 & 4.084 & $\mathbf{0 . 5 3 0}$ & 0.567 \\
DIS.03 & 27.2727 & 4.200 & $\mathbf{0 . 4 2 7}$ & 0.527 \\
DIS.04 & 27.2121 & 4.413 & $\mathbf{0 . 5 6 5}$ & 0.466
\end{tabular}




\begin{tabular}{|l|l|l|l|l|} 
DIS.05 & 27.1515 & 4.526 & $\mathbf{0 . 3 6 3}$ & 0.465 \\
DIS.06 & 27.1212 & 4.031 & $\mathbf{0 . 3 7 9}$ & 0.542 \\
DIS.07 & 27.2121 & 4.611 & $\mathbf{0 . 6 0 8}$ & .0313 \\
DIS.08 & 27.1515 & 4.542 & $\mathbf{0 7 2 9}$ & 0.488 \\
\hline
\end{tabular}

Sumber : Output SPSS Diolah'2018

Tabel 4.1.3

Validasi Variabel Kinerja

\begin{tabular}{|l|c|c|c|c|}
\hline & $\begin{array}{c}\text { Scale Mean if } \\
\text { Item Deleted }\end{array}$ & $\begin{array}{c}\text { Scale Variance if } \\
\text { Item Deleted }\end{array}$ & $\begin{array}{c}\text { Corrected Item- } \\
\text { Total Correlation }\end{array}$ & $\begin{array}{c}\text { Cronbach's Alpha } \\
\text { if Item Deleted }\end{array}$ \\
\hline KJ.01 & 38.2500 & 2.876 & $\mathbf{0 . 5 3 9}$ & 0.797 \\
KJ.02 & 38.3561 & 3.422 & $\mathbf{0 . 6 5 5}$ & 0.478 \\
KJ.03 & 38.4318 & 3.117 & $\mathbf{0 . 5 3 0}$ & 0.657 \\
KJ.04 & 38.3712 & 3.319 & $\mathbf{0 . 4 0 8}$ & 0.550 \\
KJ.05 & 38.3864 & 3.018 & $\mathbf{0 . 3 9 3}$ & 0.713 \\
KJ.06 & 38.3182 & 3.440 & $\mathbf{0 . 4 6 0}$ & 0.473 \\
KJ.07 & 38.2803 & 3.241 & $\mathbf{0 . 5 9 1}$ & 0.569 \\
KJ.08 & 38.2576 & 3.368 & $\mathbf{0 . 4 3 3}$ & 0.511 \\
KJ.09 & 38.3258 & 2.786 & $\mathbf{0 . 3 2 4}$ & 0.836 \\
KJ.10 & 38.3333 & 3.216 & $\mathbf{0 . 3 7 4}$ & 0.595 \\
KJ.11 & 38.2803 & 2.997 & $\mathbf{0 . 3 8 7}$ & 0.723 \\
\hline
\end{tabular}

Sumber : Output SPSS Diolah; 2018

Dalam table-tabel di atas, bahwa 7 indikator variabel gaya kepemimpina nmemiliki koefisien korelasi >0,30, dengan demikian maka seluruh indicator variabel tersebut telah memenuhi criteria validitas, sehingga instrument penelitian.

\section{2. Uji Normalitas}

Uji normalitas menguji model regresi variabel bebas dan variabel terikat mempunyai distribusi normal atau tidak. Model regresi yang baik adalah apabila distribusi normal atau mendekati normal. Jika data menyebar jauh dari diagonal dan atau tidak mengikuti arah garis diagonal atau grafik histogram tidak menunjukkan pola distribusi normal, maka model regresi tidak memenuhi asumsi normalitas.

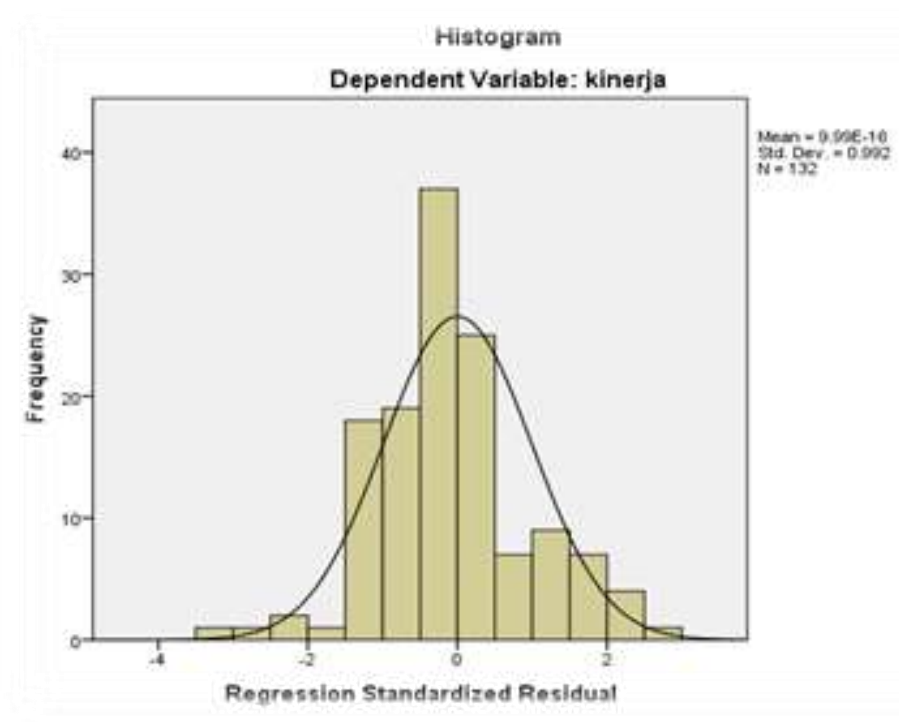


Berdasarkan grafik histogram dan grafik normal probability plot pada grafik di atas, maka dapat disimpulkan bahwa grafik histogram memberikan pola distribusi yang mendekati normal. Sedangkan pada grafik normal probability plot terlihat titik-titik menyebar disekitar garis diagonal, serta penyebarannya mengikuti arah garis diagonal.

\subsection{Uji Multikolinearitas}

Uji Multikolenearitas menguji suatu model regresi terdapat atau tidak adanya hubungan yang kuat antar variabelvariabel bebas.

Tabel 4.3.

\section{Hasil Uji Multikolinearitas}

\begin{tabular}{|ll|c|c|}
\hline \multirow{2}{*}{ Model } & \multicolumn{2}{|c|}{ Collinearity Statistics } \\
\cline { 2 - 3 } & Tolerance & VIF \\
\hline $1 \quad$ (Constant) & & \\
& Gaya Kepemimpinan & 0.992 & 1.008 \\
DisiplinKerja & 0.992 & 1.008 \\
\hline
\end{tabular}

Dependent Variabel: Kinerja

Informasi tabel di atas bahwa semua toleransi variabel bebas di atas $10 \%$ seperti halnya gaya kepemimpinan 0,992 atau 99,2\%, nilai disiplin kerja 0,992 atau 99,2\%. Dan nilai VIF gaya kepemimpinan dan disiplin kerja 1,008<5 Maka dapat disimpulkan bahwa semua variabel bebas penelitian gaya kepemimpinan dengan disiplin kerja tidak terdapat multikoleniaritas. Dengan demikian estimasi regresi hasil pengujian tidak terjadi multikolinearitas.

\subsection{Hasil Uji Hipotesis}

\subsubsection{Hipotesis 1}

Dalam penelitian ini terdapat 3 hipotesis yang akan dikonfirmasi kebenarannya, hasil pengujian hipotesis penelitian sebagaimana diuraikan sebagai berikut;

Hipotesis-1

$\mathrm{H}_{\mathrm{o}} \quad$ : Tidak Terdapat Pengaruh Gaya Kepemimpinan Terhadap Kinerja

$\mathrm{H}_{1} \quad$ : Terdapat Pengaruh Gaya Kepemimpinan Terhadap Kinerja

4.4. 1.Pengaruh Gaya Kemimpinan

Terhadap Kinerja

\begin{tabular}{|c|r|r|c|c|c|}
\hline \multirow{3}{*}{ Model } & \multicolumn{2}{|c|}{$\begin{array}{c}\text { Unstandardized } \\
\text { Coefficients }\end{array}$} & $\begin{array}{c}\text { Standard } \\
\text { ized } \\
\text { Coefficie } \\
\text { nts }\end{array}$ & T & Sig. \\
\cline { 2 - 4 } & $\mathrm{B}$ & $\begin{array}{c}\text { Std. } \\
\text { Error }\end{array}$ & Beta & & \\
\hline $\begin{array}{c}\text { Gaya } \\
\text { Kepemipinan }\end{array}$ & 0.620 & 0.122 & 0.523 & 6.499 & 0.000 \\
\hline
\end{tabular}

Sumber : Output SPSS Diolah’2018

Dari tabel di atas diketahui bahwa tingkat signifikansi pengaruh gaya kepemimpinan terhadap kinerja adalah $0,00<0,05$ dan $\mathrm{t}$ hitung 6,499>t tabel 1,993, maka hasil penelitian ini berhasil mengkonfirmasi teori penelitian bahwa terdapat pengaruh gaya kepemimpinan terhadap kinerja dapat dibuktikan.

\subsubsection{Uji Hipotesis 2}

$\mathrm{H}_{\mathrm{o}} \quad$ : Tidak Terdapat Pengaruh Disiplin Kerja Terhadap Kinerja

$\mathrm{H}_{2}$ : Terdapat Pengaruh Disiplin Kerja Terhadap Kinerja

Dari hasil pengolahan data menggunakan SPSS, dan pengujian data menggunakan uji t bahwa t hitung sebesar 4.021> dengan $\mathrm{t}$ tabel 1.993 dan tingkat signifikansi $0,025<0,05$, maka hipotesis $\mathrm{H}_{\mathrm{o}}$ ditolak dan $\mathrm{H}_{1}$ diterima maka hasil pengujian hipotesis bahwa terdapat pengaruh positif dan signifikan disiplin 
kerja terhadap kinerja, sebagaimana dalam tabel berikut.

Tabel 4.4.2

Pengaruh Disiplin Kerja Terhadap Kinerja

\begin{tabular}{|c|c|c|c|c|c|}
\hline \multirow{2}{*}{ Model } & \multicolumn{2}{|c|}{$\begin{array}{c}\text { Unstandardized } \\
\text { Coefficients }\end{array}$} & $\begin{array}{l}\text { Standardized } \\
\text { Coefficients }\end{array}$ & \multirow{2}{*}{$\mathrm{T}$} & \multirow{2}{*}{ Sig. } \\
\cline { 2 - 4 } & $\mathrm{B}$ & Std. Error & Beta & & \\
\hline $\begin{array}{c}\text { Disiplin } \\
\text { Kerja }\end{array}$ & 0.620 & 0.122 & 0.323 & 4.021 & 0.025 \\
\hline
\end{tabular}

Sumber : Output SPSS Diolah'2018

\subsubsection{Hipotesis 3}

$\mathrm{H}_{\mathrm{o}}$ : Tidak Terdapat Pengaruh Gaya Kepemimpinan dan Disiplin Kerja Secara Bersama-sama Terhadap Kinerja

$\mathrm{H}_{3}$ : Terdapat Pengaruh Gaya Kepemimpinan dan Disiplin Kerja secara bersama-sama Terhadap Kinerja

Dari hasil pengolahan data menggunakan SPSS, dan pengujian data menggunakan uji $\mathrm{F}$ bahwa $\mathrm{F}$ hitung sebesar 9,980> dengan Ftabel 1.993 dan tingkat signifikansi $0,04<0,05$, maka hipotesis $\mathrm{H}_{\mathrm{o}}$ ditolak dan $\mathrm{H}_{1}$ diterima maka hasil pengujian hipotesis bahwa terdapat pengaruh positif dan signifikan gaya kepemimpinan dan disiplin kerja secara bersama-sama terhadap kinerja, sebagaimana dalam tabel berikut.

Tabel 4.4.3.

Pengaruh Gaya Kepemimpinan Dan

Disiplin Kerja Secara Bersama-sama Terhadap Kinerja.

\begin{tabular}{|c|c|c|c|c|c|}
\hline Model & $\begin{array}{c}\text { Sum of } \\
\text { Squares }\end{array}$ & Df & $\begin{array}{c}\text { Mean } \\
\text { Square }\end{array}$ & F & Sig. \\
\hline Regression & 569.588 & 3 & 156.529 & 9.980 & .04 \\
\hline
\end{tabular}

Sumber : Output SPSS Diolah'2018
4.5. Analisis Pengaruh Disiplin Kerja Terhadap Kinerja Anggota POLRI dan ASN Ditreskrimum Polda Sumsel

Disiplin kerja pegawai yang baik akan dapat meningkatkan kinerjanya, semakin baik disiplin kerja akan semakin meningkat pula kinerja. Pengaruh disiplin kerja terhadap kinerja Pada Ditreskrimum Polda Sumsel dalam penelitian ini sangat tinggi mencapai 0,576 atau $57,6 \%$, sebagaimana di gambaran dalam tabel di bawah ini.

Tabel 4.5.

Besaran Pengaruh Disiplin Kerja Terhadap Kinerja

\begin{tabular}{|c|c|c|c|c|}
\hline Model & $\mathrm{R}$ & $\begin{array}{c}\mathrm{R} \\
\text { Square }\end{array}$ & $\begin{array}{c}\text { Adjusted R } \\
\text { Square }\end{array}$ & $\begin{array}{c}\text { Std. Error of } \\
\text { the Estimate }\end{array}$ \\
\hline 1 & 0.759 & 0.576 & 0.492 & 4.39921 \\
\hline
\end{tabular}

Sumber : output SPSS Diolah'2018

4.6.Analisis Pengaruh Gaya Kepeminpinan Dan Disiplin Kerja SecaraBersama-sama Terhadap Kinerja Anggota POLRI dan ASN Pada Ditreskrimum Polda Sumsel.

Penelitian ini berhasil mengkonfirmasi teoritis dengan data empiris di lapangan, secara simultan gaya kepemimpinan dan disiplin kerja memengaruhi kinerja. Secara bersama-sama determinan pengaruh kedua variabel tersebut adalah mencapai 0,461 atau $46,1 \%$, sehingga $43,9 \%$ dapat dipengaruhi oleh variasi variabel lain. Pengaruh variabel eksogen tersebut dijelaskan dalam tabel di bawah ini.

Tabel 4.6.

Besaran Pengaruh Gaya Kepemimpinan Dan Disiplin Kerja Secara BersamaSama Terhadap Kinerja 


\begin{tabular}{|c|c|c|c|c|}
\hline Model & $\mathrm{R}$ & $\begin{array}{c}\mathrm{R} \\
\text { Square }\end{array}$ & $\begin{array}{c}\text { Adjusted } \mathrm{R} \\
\text { Square }\end{array}$ & $\begin{array}{c}\text { Std. Error of the } \\
\text { Estimate }\end{array}$ \\
\hline 1 & 0.679 & 0.461 & 0.300 & 3.77570 \\
\hline
\end{tabular}

Sumber : Output SPSS Diolah'2018

\section{Kesimpulan dan Saran}

\subsection{Kesimpulan}

1) Gaya kepemimpinan memengaruhi kinerja Anggota Polri dan ASN di lingkungan Ditreskrimum Polda Sumsel secara positif dan signifikan,

2) Disiplin kerja memengaruhi kinerja Anggota POLRI dan ASN Pada Ditreskrimum Polda Sumsel secara positif dan signifikan.

3) Secara bersama-sama gaya kepemimpinan dan disiplin kerja memengaruhi kinerja Anggota Polri dan ASN Pada Ditreskrimum Polda Sumsel,

\subsection{Saran - Saran}

1) Unsur Pimpinan pada Ditreskrimum Polda Sumsel pada setiap level manajerial dipandang perlu mengembangkan gaya kepemimpinan yang sesuai dengan perkembangan pengetahuan dan kemasyarakatan sehingga gaya kepemimpinan yang digunakan dapat meningkatkan kinerja.

2) Perlu dilakukan pengembangan penelitian lebih lanjut dengan menggunakan beberapa variabel penelitian yang lain seperti variabel kompetensi, kompensasi, komitmen organisasi, iklim kerja serta budaya kerja.

\section{Daftar Pustaka}

Arikunto, Suharsimi. (2010). Manajemen Penelitian. Jakarta: Rineka Cipta.

Arlans I Wayan Arta. 2012. Pengaruh Kepemimpinan, Disiplin dan Lingkungan Kerja terhadap Kinerja Karyawan. Jurnal Perhotelan dan Pariwisata, Agustus 2012 Vol 2 No. 1 Hal $66-79$.

Cong, N. N., \& Van, D. N. (2013). Effects of Motivation and Job satisfaction on Employees' Performance at Petrovietnam Nghe An Construction Joints Stock Corporation (PVNC). International Journal of Business and Social Science,4(6).

Dharmawan, I. Made Yusa. Pengaruh Kompensasi dan Lingkungan Kerja Non Fisik terhadap Disiplin dan Kinerja Karyawan Hotel Nikki Denpasar. 2011. PhD Thesis. Tesis, Pasca Sarjana Universitas Udayana Bali.

Ghazali, Imam. 2009. Aplikasi Analisis Multivariate dengan Program SPSS, Edisi Keempat, Penerbit Universitas Diponegoro.

Firdaus, Zamzam Fakhry, 2018 Aplikasi Metodologi, Yogyakarta, Penerbit deepublish

Gibson, James, et al. (1996). Organisasi Perilaku, Struktur, dan Proses. (Alih Bahasa: Nunuk Adiarni). Jakarta: Binarupa Aksara.

Harlie, M. (2012). Pengaruh Disiplin Kerja, Motivasi dan Pengembangan Karier terhadap Kinerja PNS pada PemKab Tabalong di Tanjung Kalimantan Selatan. Jurnal 
Aplikasi Manajemen Vol. 10, No. 4, Desember 2012: 860 - 867.

Handoko, Hani T. 2010. Manajemen Personalia dan Sumber Daya Manusia. Yogyakarta : BPFE.

Hasibuan, Malayu, S.P. 2012. Manajemen Sumber Daya Manusia. Edisi Revisi : PT. Bumi Aksara. Jakarta.

Hermawati, S. (2012). Pengaruh Kemampuan, Kepuasan, dan Disiplin Kerja Terhadap Kinerja Pegawai di Lingkungan Kecamatan Kayen Kabupaten Pati (Doctoral dissertation, Universitas Muria kudus).

Hidayat,. dkk. (2005). Pengaruh Motivasi Kerja, Kemampuan Kerja, dan Gaya Kepemimpinan terhadap Kinerja Karyawan pada Badan Kesatuan Bangsa dan Perlindungan Masyarakat Propinsi Jawa Tengah. Jurnal Ilmu Administrasi dan Kebijakan Publik, Vol. 3, No. 1, Januari 2006: 89 - 97.

Karami, A., Dolatabadi, H. R., \& Rajaeepour, S. (2013). Analyzing the effectiveness of reward management system on employee performance through the mediating role of employee motivation case study: Isfahan Regional Electric Company. International Journal of Academic Research in Business and Social Sciences, 3(9), 327.

Mariam, Rani. (2009). Pengaruh Gaya Kepemimpinan dan Budaya Organisasi terhadap Kinerja Karyawan Melalui Kepuasan Kerja Karyawan sebagai Variabel Intervening. Tesis: Program Studi Magister Manajemen Program
Pasca Sarjana Universitas Diponegoro.

Mas'ud, Fuad (2004). Survey Diagnosis Organizational. Semarang; UNDIP.

Mathis, Robbert L dan Jakckson, John H. 2012. Manajemen Sumber Daya Manusia. Yogyakarta ; Salemba Empat.

Maharani, Intan Ratna dan Rahmawati, Siti. 2010. Pengaruh penerapan Disiplin Kerja terhadap prestasi kerja pegawai Dinas Pendidikan Kabupaten Ciamis. Vol 11 No. 3. Jurnal Manajemen dan Organisasi. Hal. 191 - 202.

Mangkunegara, Anwar P. 2009. Evaluasi Kinerja Sumber Daya Manusia. Bandung; PT. Refika Aditama.

Patiran, Andarias. (2010). Analisis FaktorFaktor yang Mempengaruhi Kinerja Pegawai Negeri Sipil (PNS). Jurnal Fokus Ekonomi, Vol. 5, No. 2, Desember $2010: 32-43$.

Ranupandojo, Heidjrahman dan Suad Husnan. (1984). Manajemen Personalia, Edisi Ketiga. Yogyakarta; BPFE UGM.

Robbins, Stephen, P. 2009. Prinsip prinsip Perilaku Organisasi, Jakarta. Erlangga.

Rivai, Veithzal. 2011. Manajemen Sumber Daya Manusia Untuk Perusahaan Dari Teori ke Praktek. Jakarta ; PT. Raja Grafindo Persada.

Sedarmayanti. 2011. Sumber Daya Manusia dan Produktifitas Kerja. Bandung. CV. Mandar Maju

Setyawan, Budi \& Waridin (2006). Pengaruh Disiplin Kerja Karyawan dan Budaya Organisasi terhadap 
Kinerja di Divisi Radiologi RSUP dr. Kariadi. Semarang. JRBI. Vol 2. No. 2. Hal. $181-198$.

Suranata, Sri (2002). Dampak Motovasi karyawan pada hubungan antara Gaya Kepemimpinan dengan Kinerja Karyawan perusahaan Bisnis. Jurnal, Empirika, Vol : 15(2), Desember : 116 - 138.

Simamora, Bilson. 2008. Panduan Riset Perilaku Konsumen. Jakarta. PT. Gramedia Pustaka Utama.

Suradinata, Ermaya. 2007. Pemimpin dan Kepemimpinan Pemerintah, Pendekatan Budaya, Moral dan Etika. Gramedia, Jakarta.

Suprayitno. 2007. Pengaruh Disiplin Kerja, Lingkungan Kerja Dan Motivasi Kerja Terhadap Kinerja Karyawan. Vol 2 No.1. Jurnal Manajemen Sumber Daya Manusia. Hal. 23 - 34.

Siagian, Sondang P, 2009. Manajemen Sumber Daya Manusia, Cetakan Ketujuh, Jakarta; Radar jaya Offset.

Sutrisno, Edy. (2010). Manajemen Sumber Daya Manusia. Jakarta: PT. Prenada Media Group.

Suprihatiningrum, H. \& Tri, B. (2012). Faktor-faktor yang Mempengaruhi Prestasi Kerja (Studi pada Karyawan Kantor Kementrian Agama Provinsi Jawa Tengah). Jurnal Manajemen, 1-22.

Sugiyono. (2008). Metode Penelitian Kunatitatif Kualitatif dan R \& D. Bandung: Alfabeta.
Suryana, M.Si. "Metodologi Penelitian." Jakarta. PT Raja Grafindo Persada(1995).

Umar, Husein, 2003. Riset Pemasaran dan Perilaku Konsumen Jakarta. PT. Gramedia.

Yun, S., Riki, T., \& Wei, L. (2007). Employee Self-Enhancement Motives and Job Performance Behaviors: Investigating the Moderating Effects of Employee Role Ambiguity and Managerial Perceptions of Employee Commitment. Journal of Applied Psychology, 92(3), 745-756.

Zamzam, Fakhry, Havis Aravik, 2016. Manajemen SDM Berbasis Syariah, Bogor: CV. RWTC Success

Zamzam, Fakhry, 2015, Teknik Dasar Penulisan Proposal Tesis, Palembang, Penerbit Noerfikri 